\title{
Synthesis of TiC thin films by CVD from toluene and titanium tetrachloride with nickel as catalyst
}

\author{
López-Romero, S. ; Chávez-Ramírez, J. II \\ ${ }^{\mathrm{I}}$ Instituto de Investigaciones en Materiales. Universidad Nacional Autónoma de México \\ Circuito Exterior s/n Ciudad Universitaria A. Postal 70-360 Coyoacán \\ C.P. 04510 México D.F. México Tel. 00525556224732 Fax. 00525556161251 \\ e-mail: sebas@ servidor.unam.mx \\ ${ }^{\text {II } F a c u l t a d ~ d e ~ Q u i ́ m i c a . ~ U n i v e r s i d a d ~ N a c i o n a l ~ A u t o ́ n o m a ~ d e ~ M e ́ x i c o ~}$ \\ Circuito Exterior s/n Ciudad Universitaria A. Postal 70-360 Coyoacán \\ C.P. 04510 México D.F. México Tel. 00525556224732 Fax. 00525556161251 \\ e-mail: jchavezr@correo.unam.mx
}

\section{ABSTRACT}

Titanium Carbide $\mathrm{TiC}_{\mathrm{x}}$ was deposited onto quartz substrates by the chemical vapour deposition (CVD) method. $\mathrm{TiC}_{\mathrm{x}}$ thin films were obtained from titanium tetrachloride $\left(\mathrm{TiCl}_{4}\right)$ and toluene $\left(\mathrm{C}_{6} \mathrm{H}_{5} \mathrm{CH}_{3}\right)$ as carbon source. Deposits were carried out in the range of substrate temperatures from 300 to $1100{ }^{\circ} \mathrm{C}$, with a source gas molar ratio $\left(\mathrm{C}_{6} \mathrm{H}_{5} \mathrm{CH}_{3} / \mathrm{TiCl}_{4}+\mathrm{C}_{6} \mathrm{H}_{5} \mathrm{CH}_{3}\right)$ of 0.8 . There was two deposit processes; the first was to carry out without nickel as catalyst and the second with nickel as catalyst.

Results showed that the effect of nickel as catalyst is very relevant to obtain $\mathrm{TiC}_{\mathrm{x}} . \quad \mathrm{TiC}_{0.87}$ thin films, $0.5 \mu \mathrm{m}$ thickness, were obtained for deposition temperatures above $900^{\circ} \mathrm{C}$ using nickel as catalyst. In this case a cubic structure, with a lattice parameter of $4.327 \AA$ and a hardness of 2900 Vickers, was obtained at $1100^{\circ} \mathrm{C}$. whilst for substrate temperatures between 300 to $900^{\circ} \mathrm{C}$ with nickel as catalyst amorphous carbon samples were obtained. For the samples prepared without the presence of the nickel as catalyst only $\mathrm{C}$ amorphous thin films were obtained for all deposit temperatures.

Keywords: Titanium carbides, CVD, nickel catalyst, cubic structure, lattice parameter, microhardness.

\section{$1 \quad$ INTRODUCTION}

Carbon and elements from the group IV form the transition metal carbides. From this group $\mathrm{TiC}_{\mathrm{x}}$, which assumes the $\mathrm{NaCl}$ crystal structure fcc, is a typical example [1]. $\mathrm{TiC}_{\mathrm{x}}$ has a wide range of composition, from $\mathrm{TiC}_{0.47}$ to $\mathrm{TiC}_{1.0}$, where the complement $1-\mathrm{x}$ corresponds to vacancies. Titanium carbide, $\mathrm{TiC}$, is known as one of the hardest carbides with a hardness of $1900 \mathrm{~kg} / \mathrm{mm}^{2}$ [2] at $\mathrm{TiC}_{0.8}$. Since it possesses a remarkable thermal and chemical stabilities, its melting temperature is $3067^{\circ} \mathrm{C}$ and it is not affected by acids or aqueous alkalis [3], titanium carbide is therefore of great industrial interest, i.e. as first-wall coating for fusion reactors and coating for tools and bearings $[\underline{4}, \underline{5}, \underline{6}, \underline{7}, \underline{8}]$. TiC also can be used as decorative thin films [] There are several techniques to prepare titanium carbide coatings such as ion plating (IP), sputtering, plasma enjanced chemical vapour deposition (PECVD) [10], reactive ion beam-assisted electron beam -physical vapor deposition (RIBA, EB-PVD) [11], by laser igniting self-propagating high-temperature synthesis LISHS [12], by self-propagating high-temperature synthesis SHS [13]. Thermal CVD technique has shown to be an effective mean to obtain $\mathrm{TiC}$ high purity and defect free films $[14,15,16]$.

Commercial processes involve chemical vapour deposition from hydrogen, methane and titanium tetrachloride at $1200{ }^{\circ} \mathrm{C}$ [17].In this work $\mathrm{TiC}_{\mathrm{x}}$ films were deposited on silica quartz by thermal CVD with and without nickel as catalyst. The relation between deposition conditions and the properties like hardness, structure and non-stoichiometry of $\mathrm{TiC}_{\mathrm{x}}$ films, was investigated. In addition, preferred orientation, lattice parameter and deposition rate of the $\mathrm{TiC}_{\mathrm{x}}$ films were also determined. 


\section{EXPERIMENTAL}

The experimental system was a typical hot-wall reactor, figure 1 . The reactor chamber consisted of a horizontal silica tube, $100 \mathrm{~cm}$ length and $2 \mathrm{~cm}$ diameter, placed into a furnace. $\mathrm{TiCl}_{4}$ (1) $(99.99 \%)$ and $\mathrm{C}_{6} \mathrm{H}_{5} \mathrm{CH}_{3}$ (l) (99.99\%) were used as source reactant materials and helium as carrier gas. $\mathrm{TiCl}_{4}$ (g) was introduced into the silica tube by bubbling $200 \mathrm{sccm}$ of helium (99.99\%) through a glass flask of $\mathrm{TiCl}_{4}$ (l) at $80{ }^{\circ} \mathrm{C}$. The $\mathrm{C}_{6} \mathrm{H}_{5} \mathrm{CH}_{3}$ (g) was introduced into the silica tube by bubbling $40 \mathrm{sccm}$ of helium $(99.99 \%)$ through a glass flask of $\mathrm{C}_{6} \mathrm{H}_{5} \mathrm{CH}_{3}$ (l) under a temperature of $30{ }^{\circ} \mathrm{C}$. The molar ratio of the reactants $\mathrm{TiCl}_{4}(\mathrm{~g})$ and $\mathrm{C}_{6} \mathrm{H}_{5} \mathrm{CH}_{3}(\mathrm{~g}), \mathrm{m}_{\mathrm{c}}=\left[\mathrm{C}_{6} \mathrm{H}_{5} \mathrm{CH}_{3} /\left(\mathrm{TiCl}_{4}+\mathrm{C}_{6} \mathrm{H}_{5} \mathrm{CH}_{3}\right)\right]$, was 0.8 . Nickel, which was used as catalyst, was placed in $1 \mathrm{~cm}^{2}$ area sheets alternating with the quartz substrates, figure 1 . Deposition temperatures $\left(T_{D E P}\right)$ ranged from $300{ }^{\circ} \mathrm{C}$ to $1100{ }^{\circ} \mathrm{C}$, with a deposition time of $45 \mathrm{~min}$. Under similar conditions, deposits were carried out with and without nickel as catalyst. For crystalline samples, preferred orientation and lattice parameters were investigated by X-ray diffraction (XRD) using a Siemens D 500 diffractometer, $\mathrm{CuK} \alpha$ radiation with $\lambda=1.5406 \AA$. The thickness of the films was measured with a Dektak IIA equipment. The stoichiometry of the samples was determined by EDS with a Pentafet microprobe linked to a LeicaCambridge Stereoscan 440 electron microscope. Microhardness measurements on the deposits were carried out with a Matsuzawa Seiki MXT30-UL ultra microhardness tester equipped with a Knoop indenter, suitable for measurement of extremely thin plates that are hard to be measured by the ordinary Vickers hardness testers. The deposition rate was calculated from a linear relationship between the thickness of deposits and deposition time.

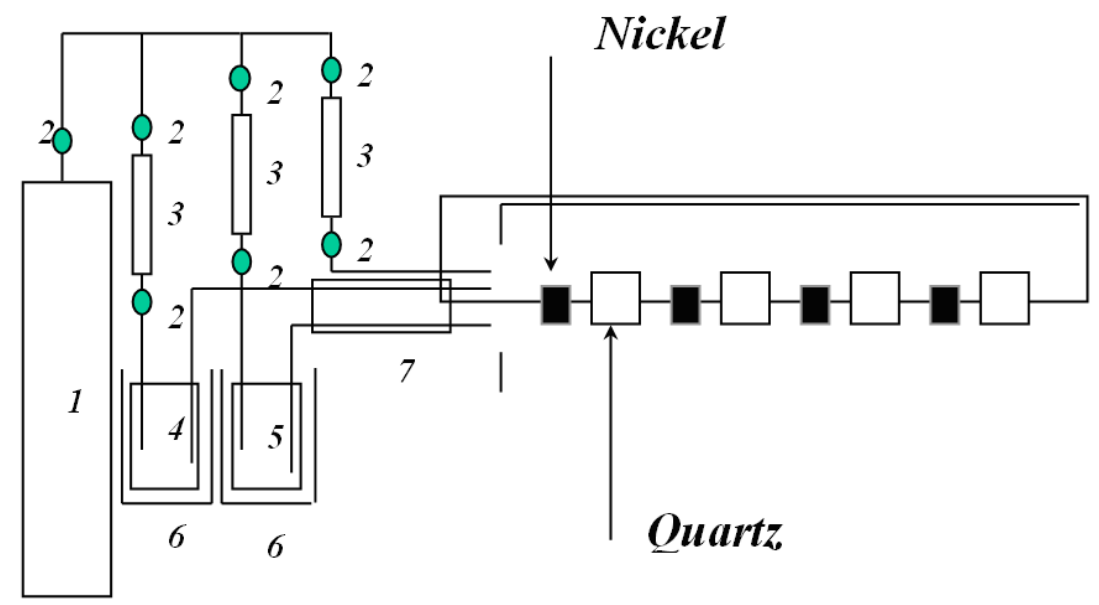

Figure 1: Schematic diagram of the CVD apparatus: 1) $\mathrm{He}(\mathrm{g}), 2)$ valve, 3) flow meter, 4) $\mathrm{TiCl}_{4}$ reservoir, 5) $\mathrm{C}_{6} \mathrm{H}_{5} \mathrm{CH}_{3}$ reservoir, 6) constant temperature bath, 7) ribbon heater, 8) horizontal silica tube and 9) furnace.

\section{RESULTS AND DISCUSSION}

\subsection{Nickel as Catalyst}

Nickel belongs to a transition metals family in which the elements are very efficient catalysts. $\mathrm{Ni}$ is widely used in the laboratory and industry in a umber of liquid-phase and gas-phase processes involving organic compounds [18]. Transition elements are distinguished of main group elements having partly filled d or $\mathrm{f}$ shells. The main transition group, or $\mathrm{d}$ - block elements have partially filled the $\mathrm{d}$ shell [19]. Nickel metal ion has, on average, 9.4 valence shell orbitals [20], $-\mathrm{s}, \mathrm{p}_{\mathrm{x}}, \mathrm{p}_{\mathrm{y}}, \mathrm{p}_{\mathrm{z}}, \mathrm{d}_{\mathrm{z}}{ }^{2}, \mathrm{~d}_{\mathrm{x}-\mathrm{y}}{ }^{2}, \mathrm{~d}_{\mathrm{xy}}, \mathrm{d}_{\mathrm{xz}}, \mathrm{d}_{\mathrm{yz}}-$ to accommodate its valence electrons to form hybrid molecular orbitals bonded to other groups [18]. These valence orbitals inherent to nickel metal give the capacity to form both sigma $(\sigma)$ and pi $(\Pi)$ bonds with other moieties or ligands. This is an ability to form those bonds, one of them is the key factor imparting catalytic properties to the nickel metal and its complexes [19].

In this work, the reaction between titanium tetrachloride and toluene to obtain titanium carbide may be described as

$$
7 \mathrm{TiCl}_{4}+\mathrm{C}_{6} \mathrm{H}_{5} \mathrm{CH}_{3}+\mathrm{Ni} \text { (catalyst) } 7 \mathrm{TiC}+8 \mathrm{HCl}+10 \mathrm{Cl}_{2}
$$


The presence of $\mathrm{HCl}$ and gas chloride as reaction products were detected by conventional methods, however it is necessary to carry out a detailed study about the kinetic of the reaction to elucidate the role of the nickel as catalyst in this process. This work is in progress.

\subsection{Structure and Film Composition}

\subsubsection{Without nickel}

$\mathrm{X}$-ray diffraction patterns of $\mathrm{TiC}$ thin films deposited on fused quartz substrates of $1 \mathrm{~cm}^{2}$, at different temperatures, $300{ }^{\circ} \mathrm{C}$ to $600^{\circ} \mathrm{C}$, without the nickel presence, are shown in figure 2 . These patterns showed only broad curves, characteristic of graphitic amorphous carbon..

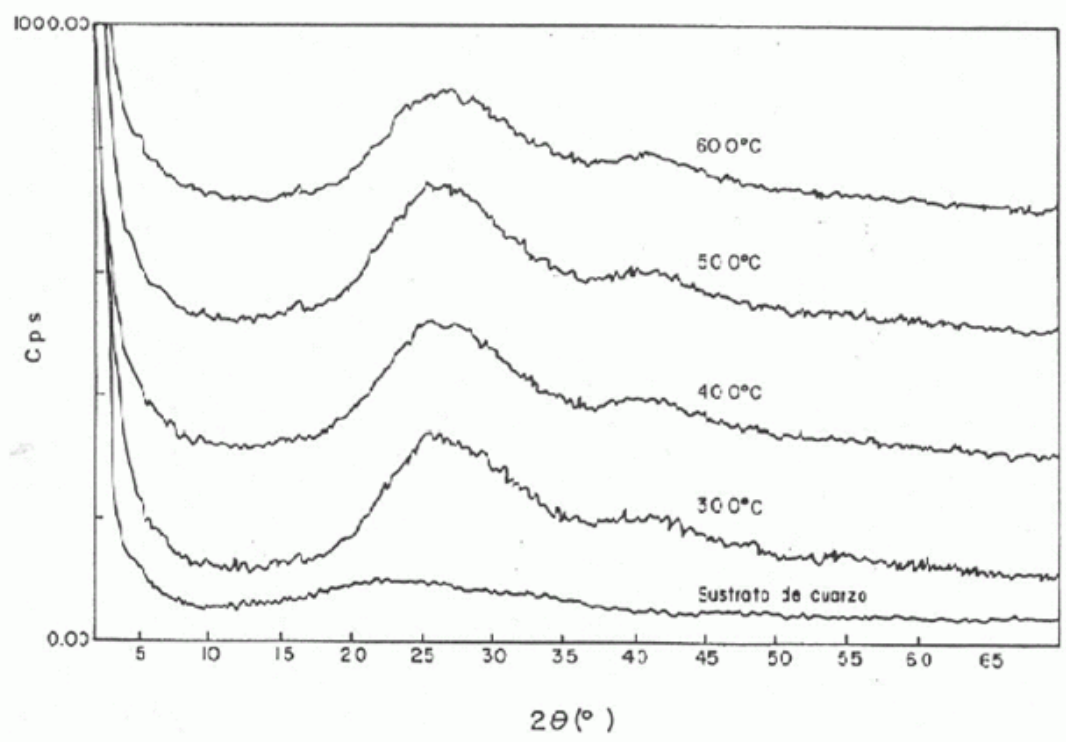

Figure 2: X-ray diffractograms pattern of the amorphous carbon thin films prepared at differents temperatures without nickel as catalyst.

Figure 3 shows the $\mathrm{X}$-ray diffraction patterns of TiC films, which were deposited at substrate temperatures of $700{ }^{\circ} \mathrm{C}$ to $1100^{\circ} \mathrm{C}$ without nickel as catalist. This patterns also showed the amorphous character of the TiC films.

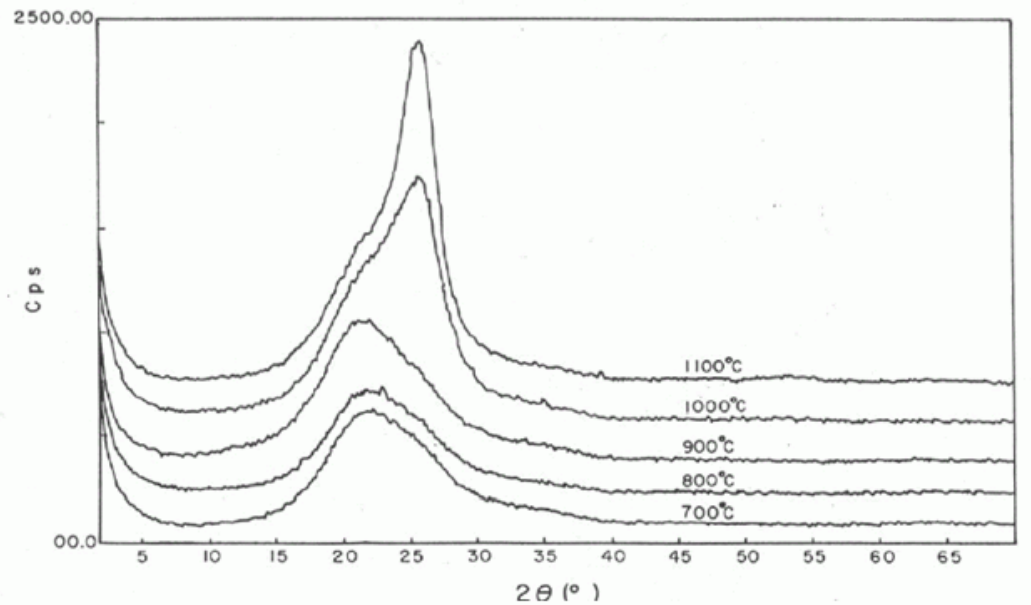

Figure 3: XRD analysis of the amorphous carbon thin films prepared at differents temperatures without nickel as catalyst. 


\subsubsection{With nickel}

Figures 4 and 5 shows the X-ray diffractograms of the TiC films prepared at $300-600^{\circ} \mathrm{C}$,

$700-900^{\circ} \mathrm{C}$ temperature intervals's with nickel as catalyst respectively, it is clearly observed that this TiC films are amorphous. X-ray diffraction patterns of the samples prepared at, 1000 and $1100{ }^{\circ} \mathrm{C}$, using nickel as catalyst during the deposit process, are showed in figure 6. XRD patterns exhibited intense peaks at 35.94, 42.71 and $60.452 \theta$ degrees, for the two deposition temperatures. These strong reflections are associated to the fcc structure of the TiC phase [21]. The lattice parameter a of TiC was calculated from the $\mathrm{d}$ spacing using the most intense peaks. Results indicated that these carbides are cubic with a cell parameter $\mathrm{a}=$ $4.3270 \AA$, which matches well the standard JCPDS $6-1614$, also similar to the value $\mathrm{a}=4.3285 \AA$ which was reported for the bulk standard [2], this a value is also consistent to that reported by Norton and Lewis [20].

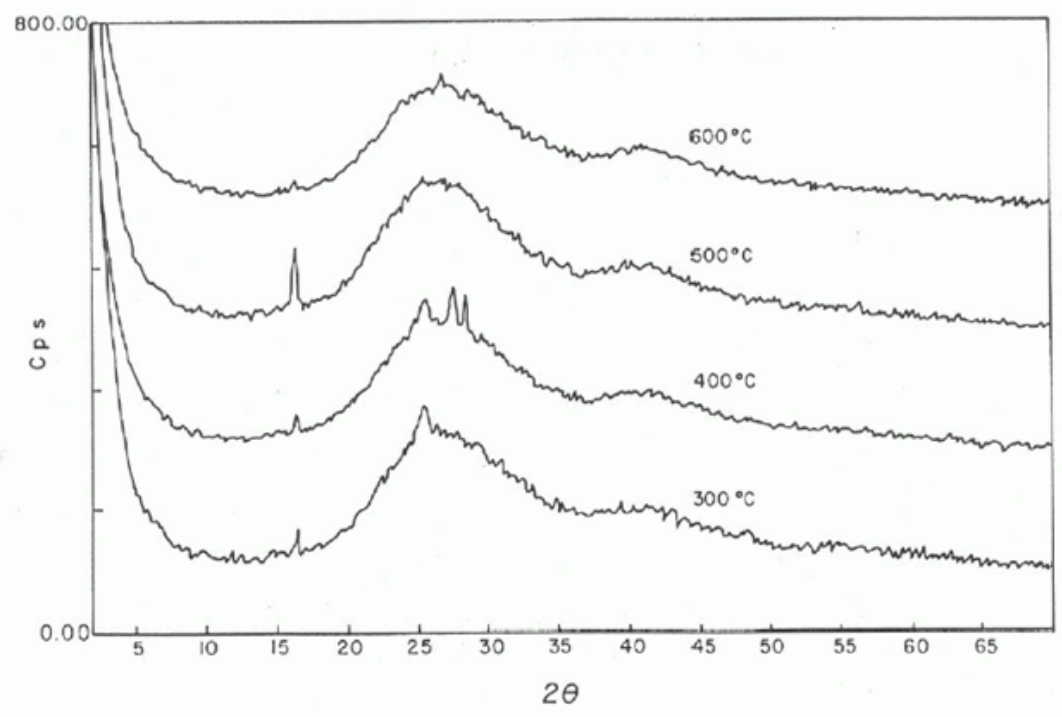

Figure 4: X-ray diffractograms of amorphous carbon thin films prepared at differents temperatures with nickel as catalyst.

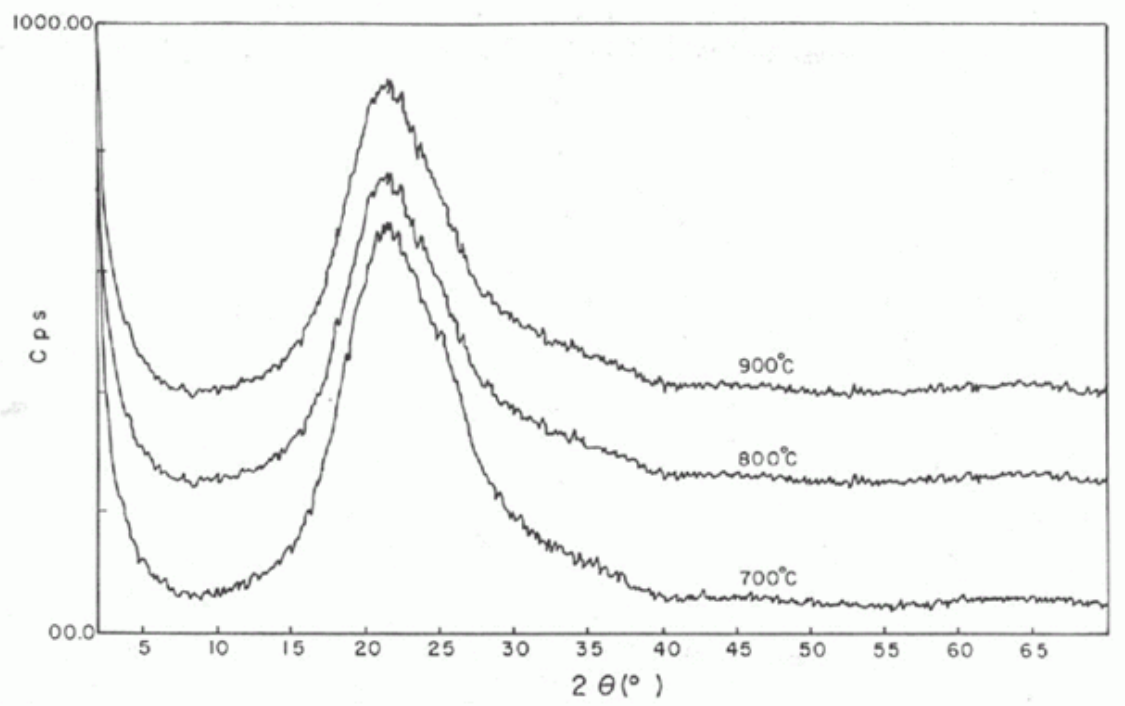

Figure 5: X-Ray diffractograms of amorphous carbon thin films prepared at differents temperatures with nickel as catalyst. 


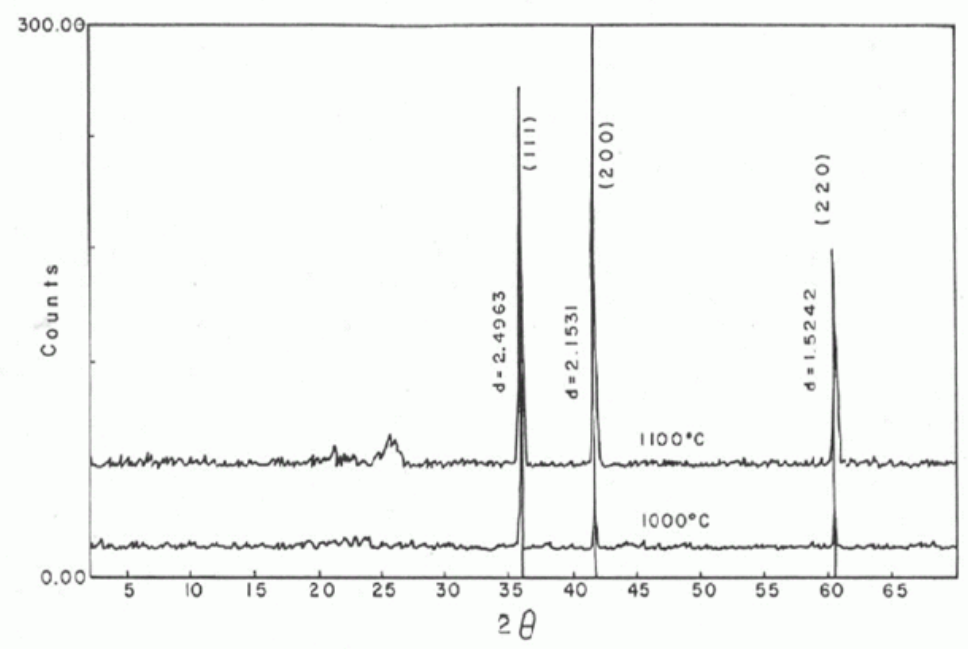

Figure 6: X-Ray diffractograms of $\mathrm{TiC}$ thin films prepared at 1000 and $1100^{\circ} \mathrm{C}$ with nickel as catalyst.

The composition ratio $\mathrm{x}(\mathrm{x}=\mathrm{C} / \mathrm{Ti})$ obtained by EDS resulted to be approximately the same value for the two deposit temperatures, $\mathrm{x}=0.87$. This result is consistent with the study realized by Guinier [21] on TiC obtained by ARE; however these authors concluded that for high values of the molar fraction $(>0.7) \mathrm{x}$ and a are independent of deposition temperature, in this temperature range.

The crystallite size, which were estimated from the full width at half maximum peak using the Scherrer equation [22], was $230 \mathrm{~nm}$.

\subsection{Microhardness}

With the use of the indenter Knoop it is possible to measure an indentation length min. of 0.01 microm or $100 \mathrm{~nm}$. We have TiC films with thickness $>500 \mathrm{~nm}$, for that reason, we can be sure that the hardness measurements are of the TiC thin films. For the hardness measurements a load of $50 \mathrm{~g}$ was used.

The microhardness of $\mathrm{TiC}$ film shows a marked dependence on the substrate temperature. Microhardness results of the crystalline $\mathrm{TiC}$ films which were deposited in the range temperature $1000^{\circ} \mathrm{C}-$ $1100^{\circ} \mathrm{C}$ are summarized in Table 1.

Table 1: Microhardness for crystalline TiC films as a function of the substrate temperature.

\begin{tabular}{|c|c|}
\hline Substrate Temperature $\left({ }^{\mathbf{o}} \mathbf{C}\right)$ & Microhardness (50 g load) (Vickers) \\
\hline 1000 & 2500 \\
\hline 1100 & 2900 \\
\hline
\end{tabular}
$[21, \underline{23}]$.

These results are similar to those which were reported by Bunshah's group on ARE deposited films

\section{CONCLUSIONS}

Thermal CVD of toluene and titanium tetrachloride were carried out at deposition temperature range $300-1100{ }^{\circ} \mathrm{C}$ on quartz substrates using helium as carrier gas.

Deposits were obtained with and without nickel as catalyst. Below $900{ }^{\circ} \mathrm{C}, \mathrm{X}$-ray diffraction revealed that the films prepared with nickel as catalyst are of amorphous carbon, whilst those films deposited betwen 300 to $1100^{\circ} \mathrm{C}$ without nickel as catalyst all exhibited amorphous carbon.

$\mathrm{TiC}_{0.87}$ films with fcc structure and lattice parameter of $4.3270 \AA$ were obtained using nickel as catalyst and substrate temperatures of 1000-1100 ${ }^{\circ} \mathrm{C}$. This films exhibited 2500 and 2900 microhardness vickers respectively. 


\section{ACKNOWLEDGEMENTS}

We would like to thank L. Baños and J. Guzmán for their technical assistance.

\section{BIBLIOGRAPHY}

[1] CADOFF, Y., NIELSEN, J.P., "Synthesis of TiC by Arc.Melting", Journal of Metals, v. 5, pp. 248-256, 1953.

[2] STORMS, E.K., “The refractory carbides”, v. 2, New York, USA, Academic Press, 1967.

[3] WILLIAMS, W.S., “Transition-Metals Carbides”, Progress in Solid-State Chemistry, v. 6, pp. 57-118, Jan 1971

[4] SCHAWARZKOP, P., KIEFFERR, P., LESZYNSKY, W., BENESOVSKY, F., Refractory hard metals, New York, USA, Macmillan, 1953.

[5] TOTH, L.E., Transition metal carbides and nitrides, New York, USA, Academic Press, 1971.

[6] KURISHITA, H., AMANO, Y., KOBAYASHY, S., et al, "Development of ultra-fine grained W-TiC and their mechanical properties for fusion applications", Journal of nuclear Materials, v. 367-370, pp. 1453-1457, 2007.

[7] GUO, J., BIN-SHI, X., HAI-DOU, W., et al, "Investigation on the formation and wear resistance of TiC coatings", Materials Science and Engineering A., v. 435-436, pp. 355-359, July 2006.

[8] RAZAVI, M., RAHIMIPPOUR, M., HOSSEIN, A., et al, "Effect of nanocrystaline TiC pouder addition on the hardness and wear ressistance of cast iron", Materials Science and Engineering A., v. 454455, pp. 144-147, 2007.

[9] FERNANDEZ, A.C., VAZ, F., CUNJA, L., et al, "The influence of structure changes in the properties of $\mathrm{Tic}_{\mathrm{x}} \mathrm{O}_{\mathrm{y}}$ decorative thin films", Thin Solid Films, v. 515, pp. 5424-5429, 2007.

[10] HINTERMANN, H.E., GASS, H., SCHEWEIZ, H.A., "Organometalic route to the chemical vapour deposition of the titanium carbide films", Angew. Wiss. Tech., v. 33, pp. 3-10, 1967.

[11] WOLFE, D.E., SING, J., "Titanium carbide coatings deposited by reactive ion bean-assisted, electron bean-physical vapour deposition", Surface and Coating Technology, v. 124, pp. 142-153, 2000.

[12] LI, Y.X., HU, J.D., WANG, H.Y., et al, "Thermodinamic and lattice parameter calculations of TiC ${ }_{x}$ produced from Al-Ti- C powders by laser igniting self-propagating high-temperature synthesis", Materials Science and Engineering A., v. 458, pp. 235-239, 2007.

[13] COCHEPIN, B., GAUHTIER, V., VREL, D., et al, "Cristal growth of TiC grains during SHS reactions", Journal of Crystal Growth, v. 304, pp. 481-486, 2007.

[14] CAO, L.X., FENG, Z.C., LIANG, Y., et al, “Thin films of TiC by CVD”, Thin Solid Films, v. 257, pp. 7-14, 1995.

[15] SHI, R., MENG, W.J., EVANS, R. P., "Characterization of high temperature deposited Ti-containing hydrogenated carbon thin films", Journal Applied Physics II, v. 96, pp. 7705-7709, 2004.

[16] KONYASIN, I.Y., "Thin $\mathrm{TiC}_{\mathrm{x}}$ films chemically vapour deposited onto cemented carbides from $\mathrm{TiCl}_{4}$ $\mathrm{CCl}_{4}-\mathrm{H}_{2}$ mixture", Thin Solid Films, v. 278, pp. 37-44, 1996.

[17] LEE, M., RICHMAN, M.H., "Chemical vapour deposition of a TiC coating cemented-carbide cutting tool”, Journal of The Electrochemical Society, v. 120, pp. 993-948, 1973.

[18] STORMS, E.K., “Thermodynamics”, International Atomic Energy Agency, v. 1, Vienna, 1966. 
[19] RANDHAWA, H., "Cathodic plasma deposition of $\mathrm{TiC}$ and $\mathrm{TiC}_{\mathrm{x}} \mathrm{N}_{1-\mathrm{x}}$ films", Thin Solid Films, v. 153, pp. 209-218, 1987.

[20] NORTON, J.T., LEWIS, R.K., Advanced Metals Research Corp, pp. N63-18389, Somerville, Massachusetts, 1963.

[21] GUINIER, A., Theore et technique of the radiocristalographie Dunod, Paris, 1964.

[22] RAGHURAM, A.C., BUNSHAH, R.F., WAGNER, C.N.J., "Structure and relationships in Ti, Zr. Ans Hf-3Zr carbide deposits, synthesized by activated reactive evaporation”, Thin Solid Films, v. 20, pp. 187-192, 1974.

[23] JACOBSON, B.E., BUNSHAH, R.F., "Transmission electron microscopy of TiC and WC_TiC deposits prepared by activated reactive evaporation", Thin Solid Films, v. 54, pp. 104-108, 1978. 